\title{
REPRODUCTIVE PHYSIOLOGY OF THE POST PARTUM COW
}

\author{
II. PITUITARY, ADRENAL AND THYROID FUNGTION \\ W. G. WAGNER,* RAYMOND SAATMAN AND \\ WILLIAM HANSEL
}

Department of Animal Science, Cornell University, Ithaca, New York

(Received 2nd May 1968, accepted 29th fuly 1968)

\begin{abstract}
Summary. There was a non-significant rise in pituitary LH concentration from Day 7 post partum $(2.07 \mu \mathrm{g} / \mathrm{mg}$ fresh anterior pituitary) to Day 30 post partum $(2.62 \mu \mathrm{g} / \mathrm{mg})$. Neither nursing of calves nor anaemia caused a significant change in pituitary LH content. Both control and thyroprotein-fed non-post partum cows had significantly higher levels of pituitary LH, $7.4 \mu \mathrm{g}$ and $6.9 \mu \mathrm{g}$ respectively, than did the post partum cows.

There was no detectable TSH in pituitaries of five of six thyroproteinfed cows. TSH concentration ranged from 2.0 to $9.5 \mathrm{mU}$ NIH-TSH-B $3 / \mathrm{mg}$ fresh pituitary in the remaining animals, but there were no significant differences between any of the groups. Thyroprotein-fed animals also had significantly lower thyroid cell heights than all other groups.

Adrenal data indicate a positive correlation exists between progesterone and cortisol in the same gland $(\mathrm{r}=0.67, P<0.01)$. The only group difference of significance was that the nursed group had a significantly lower adrenal progesterone than did the milked group (0.63 versus 1.76 $\mu \mathrm{g} / \mathrm{g})$. Cortisol content was also lower in the nursed animals, but not to a significant extent.
\end{abstract}

\section{INTRODUCTION}

Only limited data are available on pituitary gonadotrophin contents in post partum cows. Saiduddin \& Foote (1964) reported that levels of luteinizing hormone (LH) increased from 6.6 to $21 \cdot 1 \mu \mathrm{g} \mathrm{NIH-LH-sI/mg} \mathrm{dry} \mathrm{anterior} \mathrm{pituitary,}$ between Day 5 and Day 30 post partum in nursing beef cows. Labhsetwar, Collins, Tyler \& Casida (1964) reported pituitary LH contents were lower at parturition than at Days 260 to 265 of pregnancy, or at Day 21 post partum. These workers also reported that pituitary FSH was highest at parturition and declined significantly by Day 21 post partum.

Saiduddin, Riesen, Graves, Tyler \& Casida (1966) reported that pituitary LH content was increased at Days 10,20 or 30 post partum when compared to levels found at parturition.

* Present address: Veterinary Medical Research Institute, Iowa State University, Ames, Iowa 50010. 
The adrenal appears to be involved in several reproductive problems (Van Rensburg, 1965). Adrenal progesterone levels were reported to be from 0.5 to $0.7 \mu \mathrm{g} / \mathrm{g}$ of adrenal tissue by Stormshak \& Erb (1961), and Moody (1964) reported very high levels (3 to $4 \mu \mathrm{g} / \mathrm{g}$ of adrenal) in heat-stressed animals.

Leech \& Bailey (1953) reported that thyroprotein feeding had no effect on services per conception in cattle. Louw, Erasmus, Mouton \& Hansel (1964) presented evidence for a thyrotropic effect of oestrogens fed to sheep, and postulated that it occurred by way of a mechanism involving a reciprocal relationship between pituitary $\mathrm{LH}$ and thyroid-stimulating hormone (TSH).

\section{MATERIALS AND METHODS}

Animals

A total of forty-four animals was used as follows.

Group 1 (Day 7): slaughtered at 7 days post partum.

Group 2 (Day 14): slaughtered at 14 days post partum.

Group 3 (Day 30 milked): slaughtered at 30 days post partum, or on Day 19 of the oestrous cycle if oestrus was detected before Day 30.

Group 4 (Day 30 nursed): slaughtered under the same schedule as Group 3, and all nursed calves during the entire post partum interval.

Group 5 (Day 30 anaemic): slaughtered under the same schedule as Groups 3 and 4 , and were bled at frequent intervals to produce mild anaemia.

Group 6 (cyclic control) : normal, cycling animals slaughtered at about Day 19 of the oestrous cycle.

Group 7 (thyroprotein-fed): animals fed $10 \mathrm{~g}$ thyroprotein daily (equivalent to $100 \mathrm{mg}$ L-thyroxine) and slaughtered at intervals of 107 to 347 days post partum. Three animals, in which oestrus had been detected, were slaughtered at Day 19 of the oestrous cycle.

\section{Necropsy procedures}

Animals were killed by stunning and bled from the neck. The pituitary, thyroid and adrenal glands were removed as soon as possible.

The anterior pituitary was trimmed free from surrounding tissue, weighed and split mid-sagitally. One half was reweighed and acetone dried, or frozen for subsequent bio-assay. Both adrenals were trimmed and weighed; a small slice was taken for histological examination, and the remaining portion reweighed and frozen in $95 \%$ ethanol for assay of cortisol and progesterone. The thyroid gland was trimmed, weighed and fixed for histological examination.

\section{Assay methods}

The uptake of ${ }^{32} \mathrm{P}$ by chick testes, as described by Florsheim, Valcoff \& Bodfish (1959), was used to assay pituitary LH. Parallel line, four-point assays were used, with NIH-LH-B3 or NIH-LH-B4 as standards. Unknowns and standards were injected subcutaneously in the left femoral space and ${ }^{32} \mathbf{P}(5 \mu \mathrm{c})$ was injected into the opposite leg $3 \mathrm{hr}$ later. The chicks were killed $20 \mathrm{hr}$ after the ${ }^{32} \mathrm{P}$ injection. Testes were trimmed, air dried, counted in a gas-flow, thin-window 
counter and weighed. The end point was expressed as counts per min per mg dry testis. The chick thyroid uptake of ${ }^{32} \mathrm{P}$ was used for the assay of pituitary TSH (Lamberg, 1953). NIH-TSH-B3 was used as the standard. Five $\mu \mathrm{C}{ }^{32} \mathrm{P}$ was injected $11 \mathrm{hr}$ after the TSH and $1 \mathrm{hr}$ before killing the chicks. The left thyroid was removed, trimmed, air dried and counted in a gas-flow, thin-window counter. Results were expressed as net counts per min.

The general procedures for adrenal progesterone and cortisol determinations are outlined in Text-fig. 1. Entire adrenals, less approximately 1-g portions

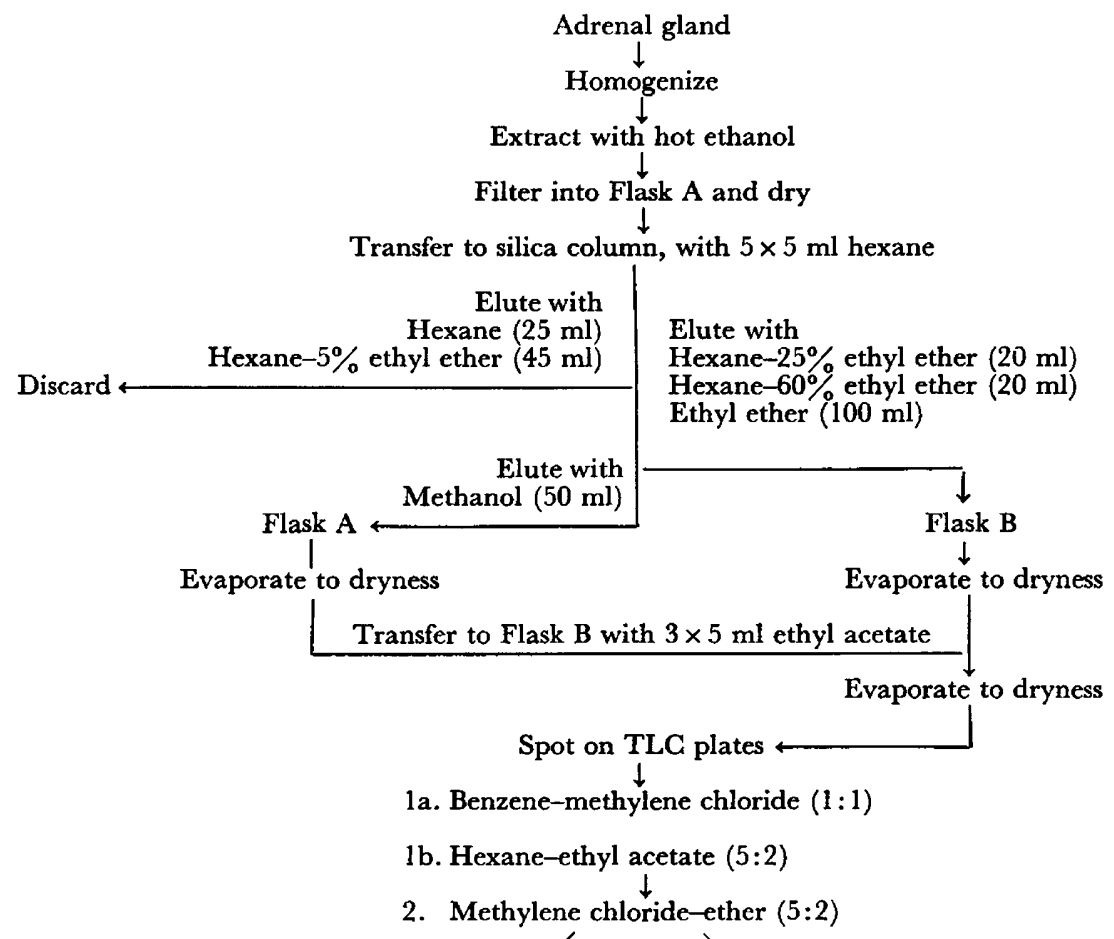

Progesterone spot scraped, eluted with ether, respotted on TLG plate

1. Hexane-ethyl acetate $(5: 2)$

2. Methylene chloride-ether $(5: 2)$

Scrape, elute in absolute ethanol, and read in spectrophotometer
Cortisol spot scraped, eluted with ethyl acetate, respotted on TLG plate

1. Chloroform-ethyl acetate (1:50) $\downarrow$

2. Methylene chloride-methanol-water $(100: 10: 1)$

Scrape, elute in absolute ethanol, and read in spectrophotometer

Text-FIG. 1. Outline of procedure for adrenal cortisol and progesterone analyses.

saved for histological examinations, were used for the assay. Each gland was homogenized and extracted three times in 100, 50 and $30 \mathrm{ml}$ of $95 \%$ ethanol for 45, 30 and $15 \mathrm{~min}$. After filtration and drying, the samples were partially purified by passing them through a 60 to 200 mesh silica gel column $19 \mathrm{~mm}$ in diameter and $40 \mathrm{~mm}$ high. 
Following an initial purification of the extract on thin layer chromatography (TLC) plates, both progesterone and cortisol were rechromatographed on a second (TLC) plate, as described in the flow sheet. The solvent systems for progesterone are described by Seifart \& Hansel (1968) and the system used for cortisol is according to Quesenberry \& Ungar (1964).

Thyroid cell heights were obtained by averaging measurements of two cells in each of five follicles in three separate sections from each thyroid.

\section{Statistical methods}

Analysis of variance and computation of coefficients of correlation were done according to Steel \& Torrie (1960). Comparisons were made for most parameters between the following groups.

\section{Day 7 versus Day 14 (1 versus 2)}

Day 30 milked versus Day 7, Day 14, Day 30 nursed, Day 30 anaemic, and cyclic control ( 3 versus 1,3 versus 2,3 versus 4,3 versus 5,3 versus 6 )

Cyclic control versus thyroprotein fed (6 versus 7$)$

Analysis of variance was done on all bio-assays to test regression and parallelism. Any unknowns that were nonparallel with the standard preparations were re-assayed in a subsequent assay. Calculation of hormone potencies and confidence limits in the LH and TSH bio-assays was done according to the method of Moore (unpublished data).

\section{RESULTS}

Pituitary LH contents are shown in Table 1. Comparison of Groups 3 versus 6 and 3 versus 7 indicated significant differences $(P<0 \cdot 01)$ in $\mathbf{L H}$ concentrations,

TABLE 1

PITUITARY LH CONTENT*

\begin{tabular}{l|c|c}
\hline \multicolumn{1}{c|}{ Group } & $\begin{array}{c}\text { Concentration } \\
(\mu g / m g \text { fresh } w t \\
\text { ant. pituitary }) \\
\text { Mean }\end{array}$ & $\begin{array}{c}\text { Total } \\
(\mu g) \\
\text { Mean }\end{array}$ \\
\hline 1. Day 7 & $2 \cdot 07 \pm 0 \cdot 22$ & 3,338 \\
2. Day 14 & $2 \cdot 19 \pm 0 \cdot 61$ & 3,977 \\
3. Day 30 milked & $2 \cdot 62 \pm 0 \cdot 41$ & 4,935 \\
4. Day 30 nursed & $2 \cdot 53 \pm 0 \cdot 27$ & 5,739 \\
5. Day 30 anaemic & $3 \cdot 36 \pm 0 \cdot 21$ & 6,284 \\
6. Cyclic control & $7 \cdot 36 \pm 2 \cdot 01$ & 12,670 \\
7. Thyroprotein-fed & $6 \cdot 85 \pm 2 \cdot 23$ & 12,539 \\
\hline
\end{tabular}

* Expressed as $\mu \mathrm{g}$ of NIH-LH-s1/mg \pm S.E. of mean.

but no other appropriate comparisons showed significant differences. Comparisons of the total amounts of LH per animal in the various groups followed the same pattern.

The TsH levels (Table 2) of animals in the thyroprotein-fed group (Group 7) were significantly lower than all other groups $(P<0.01)$. Although the TSH 
concentration was somewhat lower in Groups 2 and 4 when compared to Group 3 , this difference was not significant $(P>0.05)$.

Measurement of thyroid cell heights gave results similar to the TSH assays of the pituitaries, as indicated in Table 3. The thyroprotein group had significantly lower thyroid cell heights than all other groups $(P<0.05)$. There was

TABLE 2

PITUITARY TSH CONTENT*

\begin{tabular}{l|c|c}
\hline \multicolumn{1}{c|}{ Group } & $\begin{array}{c}\text { Concentration } \\
(m \text {-units } / m g) \\
\text { Mean }\end{array}$ & $\begin{array}{c}\text { Total } \\
(\text { m-units })\end{array}$ \\
\hline 1. Day 7 & $4 \cdot 15 \pm 0.79$ & 6532 \\
2. Day 14 & $3.06 \pm 0.25$ & 5742 \\
3. Day 30 milked & $4 \cdot 13 \pm 0.67$ & 7306 \\
4. Day 30 nursed & $3.06 \pm 0.72$ & 6784 \\
5. Day 30 anaemic & $4 \cdot 48 \pm 0.53$ & 8596 \\
6. Cyclic control & $3.59 \pm 1.56$ & 6035 \\
7. Thyroprotein-fed & $0.22 \dagger$ & - \\
\hline
\end{tabular}

* Expressed as milliunits (USP)/mg fresh anterior pituitary \pm S.E. of mean.

$\dagger$ Five of six animals had no detectable TsH present.

TABLE 3

THYROID GELL HEIGHT

\begin{tabular}{c|c|c|c|c|c|c|c}
\hline & \multicolumn{10}{|c}{ Group } \\
\cline { 2 - 6 } & Day 7 & Day 14 & $\begin{array}{c}\text { Day 30 } \\
\text { milked }\end{array}$ & $\begin{array}{c}\text { Day 30 } \\
\text { nursed }\end{array}$ & $\begin{array}{c}\text { Day 30 } \\
\text { anaemic }\end{array}$ & $\begin{array}{c}\text { Cyclic } \\
\text { control }\end{array}$ & $\begin{array}{c}\text { Thyroprotein- } \\
\text { fed }\end{array}$ \\
\hline Cell height $(\mu)$ & $10 \cdot 19$ & 9.91 & $10 \cdot 14$ & 10.55 & $9 \cdot 70$ & $9 \cdot 76$ & $7 \cdot 13$ \\
\hline
\end{tabular}

TABLE 4

PROGESTERONE AND CORTISOL LEVELS IN LEFT ADRENALS

\begin{tabular}{|c|c|c|c|}
\hline Group & Adrenal wt & $\begin{array}{l}\text { Progesterone* } \\
(\mu g / g)\end{array}$ & $\begin{array}{c}\text { Cortisol* } \\
(\mu g / g)\end{array}$ \\
\hline $\begin{array}{l}\text { 1. Day } 7 \\
\text { 2. Day } 14 \\
\text { 3. Day } 30 \text { milked } \\
\text { 4. Day } 30 \text { nursed } \\
\text { 5. Day } 30 \text { anaemic } \\
\text { 6. Cyclic control } \\
\text { 7. Thyroprotein-fed }\end{array}$ & $\begin{array}{l}13 \cdot 39 \\
13 \cdot 40 \\
14 \cdot 37 \\
17 \cdot 33 \\
14 \cdot 12 \\
13 \cdot 58 \\
13 \cdot 60\end{array}$ & $\begin{array}{l}1 \cdot 13 \pm 0.28 \\
0.97 \pm 0.15 \\
1 \cdot 76 \pm 0.29 \\
0.63 \pm 0.11 \\
1.50 \pm 0.55 \\
1 \cdot 30 \pm 0.54 \\
1.29 \pm 0.18\end{array}$ & $\begin{array}{l}2.52 \pm 0.87 \\
2.86 \pm 0.71 \\
4.06 \pm 1.08 \\
1.96 \pm 0.42 \\
3.71 \pm 1.65 \\
2.57 \pm 0.72 \\
2.08 \pm 0.30\end{array}$ \\
\hline
\end{tabular}

* Mean \pm S.E.

also a significant correlation between pituitary TSH concentration and thyroid cell height over all groups $(\mathrm{r}=0.412, P<0.05)$.

Since progesterone and cortisol values were not available for all right adrenals, a study of the data was made to ascertain the relationship between 
right and left adrenal activity. The correlation coefficient between left and right adrenal glands for cortisol was $r=0.886$, and for progesterone, $r=0.857$. Since both values are highly significant $(P<0.01)$, only values from the left adrenal of each animal were considered.

Comparisons of appropriate group means in Table 4 indicated that there were significant differences in adrenal progesterone between Groups 2 and 3 $(P<0.05)$ and between Groups 3 and $4(P<0 \cdot 01)$. For adrenal cortisol levels, the comparison of Group 3 versus Group 4 gave an $\mathrm{F}$ value of $3 \cdot 72(P<0 \cdot 10)$.

Adrenal progesterone and adrenal cortisol levels were highly correlated ( $\mathrm{r}=0.672, P<0.01)$.

The ratios of adrenal cortisol area (zona fasciculata and zona reticularis) to adrenal medullary areas were not correlated with adrenal contents of progesterone or cortisol, nor were they correlated with adrenal weights.

\section{DISGUSSION}

The bio-assay system based on uptake of ${ }^{32} \mathrm{P}$ by chick testes has not been widely used, but we have found it quite useful for assaying LH in material of relatively low FSH content. In order to study the effective dose range of this assay system for purified bovine $\mathrm{LH}$ and the response to varying dose levels of FSH, FSH was given at a dose of 4 or $8 \mu \mathrm{g}$ NIH-FSH-s3/chick, either alone or in combination with 6.38 or $25.5 \mu \mathrm{g}$ NIH-LH-B3. Statistical analyses of the results showed that there were no significant differences between the responses to $\mathrm{LH}$ alone and LH plus FSH at these dose levels.

Since pituitary LH:FSH ratios for the cow are reported to be approximately 10:1 (Rakha \& Robertson, 1965; Hackett, Hafs \& Armstrong, 1967), a dosage of bovine anterior pituitary equivalent to 12 to $15 \mu \mathrm{g}$ of $\mathrm{LH}$ would be expected to contain only $1.5 \mu \mathrm{g}$ of FSH. Our trials show that this amount will not give a measurable response, nor will it synergize with $\mathrm{LH}$ at $\mathbf{L H}$ :FSH ratios ranging from $3: 2$ to $6: 1$. Therefore, we feel that the assay offers a simple and economical method for assaying LH in material relatively low in FSH content.

There were highly significant differences between the post partum and nonpost partum groups in pituitary LH levels. Within the post partum animals there was a slight, but non-significant, increase from Day 7 to Day 30 post partum $(2.07$ to $2 \cdot 62 \mu \mathrm{g} / \mathrm{mg}$ ).

Saiduddin \& Foote (1964) reported that LH levels in post partum cows rose from 6.6 to $21.1 \mu \mathrm{g} / \mathrm{mg}$ dried pituitary between 5 and 30 days post partum. Since dry weight is approximately one fourth of the fresh, wet weight, their values would be 1.6 to $5.3 \mu \mathrm{g}$ on a fresh weight basis. The Day-30, milked, post partum cows (Group 3 ) had a mean total LH content of $4935 \mu \mathrm{g}$, similar to the $4655 \mu \mathrm{g}$ reported by Hackett et al. (1967) for Day 20 of the cycle. Both Saiduddin \& Foote (1964) and Hackett et al. (1967) used the ovarian ascorbic acid depletion assay to measure the LH content.

Labhsetwar et al. (1964) stated that LH levels were lower at parturition than 21 days post partum but did not give actual potencies. Thus, there appears to be general agreement on a rise in LH following parturition, although the exact levels reported differ, probably because different assay methods have been used. 
The high levels of pituitary LH in thyroprotein-fed anoestrous cows suggest a possible failure of the $\mathrm{LH}$-releasing mechanism, perhaps similar in nature to the marked decline in growth hormone releasing factor in starved rats reported by Meites \& Fiel (1965).

In confirmation of the report of Saiduddin et al. (1966), suckling appeared to have no effect on pituitary LH content. However, these data do not indicate the dynamics of the system that resulted in similar LH values in both milked and nursed animals.

Plasma oxytocin levels were determined in one milked and one suckled cow using the in vitro assay method of Van Dongen \& Hays (1966). Oxytocin was measurable $\left(10^{-8} \mathrm{i} . \mathrm{u} / \mathrm{ml}\right.$ or more) for $10 \mathrm{~min}$ during the milking process in the milked cow and $75 \mathrm{~min}$ after suckling in the nursed animal.

The marked depression of pituitary TSH levels following thyroprotein feeding agrees with the data of McQuillan, Trikojus, Campbell \& Turner (1948) in cattle and Bakke, Kammer \& Laurence (1964) in the human. The possible inverse relationship between pituitary LH and TSH levels, discussed in detail by Louw et al. (1964) could account for the anoestrus seen in thyroprotein-fed cows (Wagner \& Hansel, 1969). Similarly Howland, Bellows, Pope \& Gasida (1966) reported anoestrus in tri-iodothyronine-treated sheep.

There was little difference in adrenal cortisol levels among the treatment groups except for the low levels observed in the nursed animals. Tucker, Paape, Sinha, Pritchard \& Thatcher (1967) concluded that pituitary ACTH content was not influenced by nursing frequency in the rat. The positive correlation noted between adrenal progesterone and cortisol levels adds to the utility of previous data in which only adrenal progesterone was measured, and again suggests that progesterone may be an obligatory intermediate in cortisol synthesis within bovine adrenals.

Increased levels of cortisol are seen in conjunction with increased FsH activity and follicular growth in sheep and goats (Van Rensburg, 1965). Transportation stress has also been shown to initiate follicular growth and oestrus in anoestrous sheep (Braden \& Moule, 1964; Lang, 1964). It is not known whether the depressed adrenal activity in these nursed cows was related to their anoestrus.

\section{ACKNOWLEDGMENTS}

This investigation was supported in part by a U.S. Public Health Service Fellowship No. 5 F2 HD-24,800-03 from the Institute of Child Health and Human Development. The authors gratefully acknowledge the technical assistance of Mrs Carol Hall. The pituitary hormones used were furnished by the Endocrine Study Section, National Institutes of Health.

\section{REFERENGES}

Bakke, J. L., Kammer, H. \& Lawrence, N. (1964) Effect of thyroid hormone on human pituitary thyroid-stimulating hormone content. F. clin. Endocr. Metab. 24, 281.

Braden, A. W. H. \& Moule, G. R. (1964) Effects of stress on ovarian morphology and oestrus cycles in ewes. Aust. F. agric. Res. 15, 937.

Florsheim, W. H., VAlcoff, S. M. \& Bodfish, R. E. (1959) Gonadotrophin assay based on augmentation of radio phosphate uptake by the chick testis. Acta endocr., Copenh. 30, 175. 
Hacketr, A.J., Hafs, H. D. \& Armstrong, D. T. (1967) Relationships of pituitary luteinizing hormone and follicle stimulating hormone to luteal and follicular activities. F. Dairy Sci. 50, 969.

Howland, B. E., Bellows, R. A., Pope, A. L. \& Casida, L. E. (1966) Ovarian activity in ewes treated with glucose and tri-iodothyronine. 7. Anim. Sci. 25, 836.

Labhsetwar, A. P., Collins, W. E., Tyler, J. W. \& Casma, L. E. (1964) Some pituitary ovarian relationships in the periparturient cow. 7 . Reprod. Fert. 8, 85.

LAMBERG, B. A. (1953) Radioactive phosphorus as indicator in a chick assay of thyrotropic hormone. Acta med. scand. Suppl. 279.

Lang, D. R. (1964) Ovulations in Merino ewes moved by road or rail in Queensland. Proc. Aust. Soc. Anim. Prod. 5, 53.

Leegh, F. B. \& Bailey, B. L. (1953) The effect on the health of lactating cows of treatment with galactopoietic doses of thyroxine or iodinated casein. F. agric. Sci., Camb. 43, 236.

Louw, G. N., Erasmus, T., Mouton, A. \& Hansel, W. (1964) Evidence for a thyrotropic effect of diethylstilboestrol in sheep via a hypothetical pituitary mechanism. S. Afr. 7. agric. Sci. 7, 797.

McQuillan, M. T., Trikojus, V. M., Campeell, A. D. \& Turner, A. W. (1948) The prolonged administration of thyroxine to cows, with particular reference to the effects on thyroid function and on pituitary thyrotrophic hormone. Br. J. exp. Path. 29, 93.

Meites, J. \& FiEL, N. J. (1965) Effect of starvation on hypothalamic content of 'somatotropin releasing factor' and pituitary growth hormone content. Endocrinology, 77, 455.

Moody, E. L. (1964) The effect of high ambient temperatures on progesterone concentrations in the corpus luteum and adrenals of the bovine. M.S. thesis, University of Arizona.

Quesenberry, R. O. \& UngaR F. (1964) Thin layer chromatography systems for adrenal corticosteroids. Analyt. Biochem. 8, 192.

Rakha, A. M. \& Robertson, H. A. (1965) Changes in levels of follicle stimulating hormone and luteinizing hormone in the bovine pituitary gland at ovulation. 7. Endocr. 31, 245.

Satduddin, S. \& Foote, W. D. (1964) Pituitary luteinizing hormone activity of post partum bovine. 7. Anim. Sci. 23, 592.

Saiduddin, S., Riesen, J. W., Graves, W. E., Tyler, W. J. \& Gasida, L. E. (1966) Pituitary luteinizing hormone activity in the post partum cow. F. Anim. Sci. 25, 930.

SeIrart, K. H. \& Hansel, W. (1968) Some characteristics and optimum incubation conditions of in vitro progesterone synthesis by bovine corpora lutea. Endocrinology, 82, 232.

Steel, R. G. D. \& Torrie, J. H. (1960) Principles and procedures of statistics. McGraw Hill, New York.

Stormshak, F. \& ERB, R. W. (1961) Progestins in bovine corpora lutea, ovaries, and adrenal during pregnancy. 7. Dairy Sci. 44, 310.

Tucker, H. A., PaApe, M. J., Sinha, Y. N., Pritchard, D. E. \& Thatcher, W. W. (1967) Relationship among nursing frequency, lactation, pituitary prolactin, and adrenocorticotropic hormone content in rats. Proc. Soc. exp. Biol. Med. 126, 100.

Van Dongen, G. G. \& Hays, R. L. (1966) A sensitive in vitro assay for oxytocin. Endocrinology, 78, 1.

Van Rensburg, S. J. (1965) Adrenal function and fertility. $\mathcal{J l} S$. Afr. vet. med. Ass. 36, 491.

Wagner, W. C. \& Hansel, W. (1969) Reproductive physiology of the post partum cow. I. Clinical and histological findings. J. Reprod. Fert. 18, 493. 